\title{
PENGARUH MANAJEMEN SUMBER DAYA MANUSIA TERHADAP KESELAMATAN KERJA KARYAWAN PADA KANTOR PLN DOLOPO KAB. MADIUN
}

\author{
Sudarmiani \\ Dosen Prodi Pendidikan Ekonomi \\ Dewi Novita Ningsih \\ Mahasiswa Prodi Pendidikan Ekonomi FPIPS IKIP PGRI Madiun
}

\begin{abstract}
Abstrak: Penelitian ini bertujuan: (1) Untuk mengetahui manajemen sumber daya manusia pada Kantor PLN Dolopo Kab. Madiun. (2) Untuk mengetahui keselamatan kerja pada Kantor PLN Dolopo Kab. Madiun. (3) Untuk mengetahui pengaruh manajemen sumber daya manusia terhadap keselamatan kerja karyawan pada Kantor PLN Dolopo Kab. Madiun. Penelitian ini mengambil obyek pada Kantor PLN Dolopo Madiun dengan populasi sebanyak 40 orang karyawan. Variabel bebas dalam penelitian ini adalah manajemen sumber daya manusia dan variabel terikat dalam penelitian ini adalah keselamatan kerja karyawan. Pengumpulan data menggunakan metode observasi untuk mengambi data manajemen sumber daya manusia sebagai variabel bebas, kuesioner untuk mengambi data keseamatan kerja karyawan, serta menggunakan metode wawancara. Dalam menganalisis data digunakan metode statistik dengan rumus korelasi produk moment dan uji beda pengaruh. Atas dasar perhitungan tersebut dapat dibuat garis regresi sebagai berikut $\mathrm{Y}=17,091+0,573 \mathrm{X}$, artinya apabila manajemen sumber daya manusia ditingkatkan satu kali akan terjadi kenaikan keselamatan kerja karyawan sebanyak 0,573\% apabila faktor lainya tetap. Berdasarkan data diketahui bahwa besarnya nilai $r_{\text {hitung }}$ adalah 0,659 dan $\mathrm{r}_{\text {tabel }}$ 0,312 dilain pihak besarnya $\operatorname{Sig}_{\text {hitung }} 0,000$ dan $\operatorname{Sig}_{\text {pro }}$ 0,05. Hal ini berarti bahwa nilai $r_{\text {hitung }} \geq r_{\text {tabel }}(0,659 \geq 0,312)$ atau $\operatorname{Sig}_{\text {hit }} \leq \operatorname{Sig}_{\text {pro }}(0,000 \leq 0,05)$. Atas dasar korelasi tersebut dapat disimpulhan Ho ditolak, artinya ada hubungan antara Manajemen Sumber Daya Manusia dan Keselamatan Kerja Karyawan pada Kantor PLN Dolopo Kab. Madiun. Hasil menunjukkan, bahwa hasil perhitungan tersebut dapat diketahui bahwa besarnya nilai $\mathrm{t}_{\text {hitung }}$ adalah 7,189 dan $\mathrm{t}_{\text {tabel }} 1,685$ dilain pihak besarnya $\operatorname{Sig}_{\text {hitung }} 0,000$ dan $\operatorname{Sig}_{\text {pro }} 0,05$, hal ini berarti bahwa nilai $t_{\text {hitung }} \geq t_{\text {tabel }}(7,189 \geq 1,685)$ atau $\operatorname{Sig}_{\text {hitung }} \leq \operatorname{Sig}_{\text {pro }}(0,000 \leq 0,05)$. Atas dasar uji beda pengaruh tersebut dapat disimpulkan Ho ditolak, artinya ada beda pengaruh antara Manajemen Sumber Daya Manusia terhadap Keselamatan Kerja Karyawan pada Kantor PLN Dolopo Kab. Madiun.
\end{abstract}

Kata Kunci: Manajemen Sumber Daya Manusia, Keselamatan Kerja Karyawan

\section{PENDAHULUAN}

Keselamatan kerja karyawan merajuk pada perlindungan atas keamanan kerja yang dialami setiap pekerja. Perlindungan mengarah pada kondisi fisik dan mental para pekerja yang diakibatkan lingkungan kerja yang ada pada perusahaan.

Indikator-indikator dalam keselamatan kerja keryawan adalah: (a) undang-undang dan peraturan keselamatan kerja, (b) kebija- kan keselamatan kerja, (c) pemberian jaminan sosial tenaga kerja (jamsostek).

Manajemen sumber daya manusia sebagai suatu proses perencanaan, pengorganisasian, penyusunan staf, penggerakan, dan pengawasan, terhadap pengaadaan, pengembangan, pemberian kompensasi, pengintegrasian, pemeliharaan dan pemisahan tenaga kerja untuk mencapai tujuan tertentu. 
Indikator-indikator dalam manajemen sumber daya manusia adalah: (a) fungsifungsi manajemen sumber daya manusia (b) pendekatan dalam manajemen sumber daya manusia. fungsi manajerial ( manajerial functions), dan fungsi operasional (operational functions).

\section{Keselamatan kerja}

Para karyawan pada umumnya menginginkan kerja aman, sehat yang ditimbulkan dari lingkungan pekerjaan. Namun demikian pemberi kerja selalu beranggapan bahwa kecelakaan kerja adalah suatu pristiwa yang tidak dapat dihindari akibat pekerjaan. Mereka memahami akibat itu timbul karena minimnya peralatan dan kurangnya kemampuan dan ketrampilan kariawan menggunakan peralatan dan kurangnya pelatihan. Akan tetapi karena faktor biaya yang relative besar untuk keperluan itu maka kepentingan itu terabaikan. Kejadian ini banyak terjadi dinegara sedang berkembang sehingga tingkat kecelakaan kerja pada negara berkembang cenderung lebih besar daripada negara maju yang sangat memperhatikan keselamatan kerja karyawan.

Kecelakaan kerja merupakan hal yang tidak dapat ditolelir lagi kalau tidak adanya kehati-hatian dalam bekerja, pekerja harus mematuhi petunjuk keselamatan kerja, apalagi keryawan yang berhubungan langsung dengan alat produksi itu akan berbahaya terhadap keselamatanya. Tetapi kadang pekerja mengacuhkan prosedur keselamatan kerja yang sudah dibuat oaleh perusahaan, berdalih tidak nyaman dalam bekerja karena menurut andi salah satu karyawan swasta di kawasan industry tanjung mas Semarang, mengatakan bahwa memakai helm saat bekerja membuatnya pusing dan masker juga menghalangi udara yang masuk ke hidung sehingga tidak fokus bekerja, perusahaan banyak aturan yang membuat tidak nyaman.

Keselamatan dan kesehatan kerja adalah suatu pemikiran dan upaya untuk menjamin keutuhan dan kesempurnaan baik jasmaniah maupun rohaniah tenaga kerja pada khususnya, dan manusia pada umumnya, hasil karya dan budaya untuk menuju masyarakat adil dan makmur.

Keselamatan dan keamanan kerja mempunyai banyak pengaruh terhadap faktor kecelakaan, karyawan harus mematuhi standart (k3) agar tidak menjadikan hal-hal yang negative bagi diri karyawan. Terjadinya kecelakaan banyak dikarenakan oleh penyakit yang diderita karyawan tanpa sepengetahuan pengawas $(\mathrm{k} 3)$, seharusnya pengawasan terhadap kondisi fisik di terapkan saat memasuki ruang kerja agar mendeteksi sacera dini kesehatan pekerja saat akan memulai pekerjaanya. Keselamatan dan kesehatan kerja perlu diperhatikan dalam lingkungan kerja, karena kesehatan merupakan keadaan atau situasi sehat seseorang baik jasmani maupun rohani sedangkan keselamatan kerja suatu keadaan dimana para pekerja terjamin keselamatan pada saat bekerja baik itu dalam menggunakan mesin, pesawat, alat kerja, proses pengolahan juga tempat kerja dan lingkungannya juga terjamin. Apabila para pekerja dalam kondisi sehat jasmani maupun rohani dan didukung oleh sarana dan prasarana yang terjamin keselamatannya maka produktivitas kerja akan dapat ditingkatkan.

Dalam kehidupan seseorang tidak pernah lepas kaitanya dengan usaha dalam memenuhi kebutuhan hidupnya, dengan kata lain setiap manusia pasti memerlukan pekerjaan untuk mendapatkan penghasilan agar kebutuhanya dapat terpenuhi. Berbagai jenis pekerjaan dilakukan seperti berdagang, guru, bertani, nelayan, bekerja diperusahaan, pabrik, kantor dan sebagainya. Namun dalam bekerja selain mencari uang atau gaji juga melihat dari jaminan keselamatan kerja dan 
kenyamanan yang diberikan oleh perusahaan atau pabrik sehingga orang tersebut betah dan focus dalam bekerja, hal ini akan menguntungkan pihak perusahaan karena akan menambah kualitas dari barang atau jasa yang akan dihasilkan.

Ada berbagai jenis perusahaan Perseroan Terbatas yang beroperasi di Indonesia, kali ini penulis akan membahas tentang Kantor PLN Dolopo Kab. Madiun yang merupakan sebuah PERSERO (perusahaan perseroan).

Kantor PLN Dolopo Kab. Madiun adalah suatu perusahaan milik negara yang bergerak dibidang penyaluran listrik kepada masya-rakat khususnya masyarakat Dolopo. Seiring majunya perkembangan teknologi yang tentu banyak menggunakan aliran listrik membuat hampir seluruh warga menggantungkan penerangan mereka kepada PLN. Kantor PLN yang bergerak dalam bidang penyaluran tenaga listrik sangat rentan dengan kecelakaan kerja seperti terjatuh saat memperbaiki tiang listrik, resiko tersengat listrik dan resiko-resiko lainya. Karyawan merupakan faktor produksi yang sangat penting dalam menunjang sebuah keberhasilan usaha melayani masyarakat.

Oleh karena itu para karyawan harus mendapatkan perhatian secara seksama agar dapat memberikan kontribusi yang optimum dalam pekerjaan mereka. Mengingat fungsi ideal dari pelaksanaan tugas karyawan dalam unit kerja adalah fungsi pelayanan, maka unsur penting dalam penilaian kinerja karyawan adalah kepuasan pelanggan atau pihak yang dilayani walaupun seperti pada kasus PLN yang bersifat monopolistik dapat memberikan rasa keterpaksaan pada pelanggan. Hal ini membuat pihak PLN harus terus berusaha meningkatkan pelayanan sehingga masyarakat tidak hanya memiliki rasa keterpaksaan namun juga rasa percaya dan kenyamanan terhadap pihak PLN.

Tujuan Penerapan Kesehatan dan Ke- selamatan Kerja : Secara umum, kecelakaan selalu diartikan sebagai kejadian yang tidak dapat diduga. Kecelakaan kerja dapat terjadi karena kondisi yang tidak membawa keselamatan kerja, atau perbuatan yang tidak selamat. Kecelakaan kerja dapat didefinisikan sebagai setiap perbuatan atau kondisi tidak selamat yang dapat mengakibatkan kecelakaan. Berdasarkan definisi kecelakaan kerja maka lahirlah keselamatan dan kesehatan kerja yang mengatakan bahwa cara menanggulangi kecelakaan kerja adalah dengan meniadakan unsur penyebab kecelakaan dan atau mengadakan pengawasan yang ketat (Silalahi, 1995).

Keselamatan dan kesehatan kerja pada dasarnya mencari dan mengungkapkan kelemahan yang memungkinkan terjadinya kecelakaan. Fungsi ini dapat dilakukan dengan dua cara, yaitu mengungkapkan sebab-akibat suatu kecelakaan dan meneliti apakah pengendalian secara cermat dilakukan atau tidak.

Menteri Tenaga Kerja Nomer: PER.05/MEN/1996 (dalam Siswanto Sastrohadiwiryo, 2005: 45), "yang dimaksud dengan Sistem Manajemen Keselamatan dan Kesehatan Kerja adalah bagian bagian dari sistem manajemen secara keseluruhan yang meliputi organisasi, perencanaan, tanggungjawab, pelaksanaan, prodesur, proses, dan sumber daya yang dibutuhkan bagi pengembangan, penerapan, pencapaian, penkajian, dan pemeliharaan kebijakan keselamatan dan kesehatan kerja dalam rangka pengendalian resiko yang berkaitan dengan kegiatan kerja guna terciptanya tempat kerja yang aman, efisien, dan produktif".

Dari penjelasan di atas dapat disimpulkan bahwa tujuan dibuat undang-undang dan peraturan pemerintah adalah untuk mencegah dan mengurangi resiko kecelakaan kerja, juga sebagai bahan timbangan bagi para pemberi kerja untuk memprioritaskan keselamatan 
kerja karyawan sehingga para pekerja merasa aman dalam melaksanakan pekerjaanya.

Sistem Manajemen keselamatan dan kesehatan kerja karyawan adalah pengoperasian fungsi-fungsi manajemen kedalam kegiatan-kegiatan organisasi yang berkaitan dengan keselamatan dan kesehatan kerja (Wilson Bangun, 2012: 386). Sebagai penanggung jawab terhadap suatu peristiwa kecelakaan kerja, para pemberi kerja harus membuat formulir tentang kejadian peristiwa kecelakaan tersebut pada suatu organisasi tertentu. Semua bentuk dan penyebab timbulnya kecelakaan tersebut diuraikan secara jelas dan rinci untuk menentukan apakah hak karyawan dapat direalisasikan dan besarnya tanggung jawab perusahaan kepada karyawan yang mengalami kecelakaan.

Sistem Manajemen keselamatan dan kesehatan kerja karyawan adalah pengoperasian fungsi-fungsi manajemen kedalam kegiatan-kegiatan organisasi yang berkaitan dengan keselamatan dan kesehatan kerja (Wilson Bangun, 2012: 386). Sebagai penanggung jawab terhadap suatu peristiwa kecelakaan kerja, para pemberi kerja harus membuat formulir tentang kejadian peristiwa kecelakaan tersebut pada suatu organisasi tertentu. semua bentuk dan penyebab tibulnya kecelakaan tersebut diuraikan secara jelas dan rinci untuk menentukan apakah hak karyawan dapat direalisasikan dan besarnya tanggung jawab perusahaan kepada karyawan yang mengalami kecelakaan.

Manajemen sumber daya manusia merupakan suatu wadah dalam suatu organisasi yang salah satu tugasnya adalah memberikan rasa aman akan keselamatan kerja kepada karyawan sehingga karyawan juga dapat memberi kontribusi terhadap perusahaan tersebut.

Pada umumnya karyawan selain bekerja untuk mendapatkan upah, mereka juga memerlukan perlindungan kerja. Hal itu yang menyebabkan pihak manajemen sumber daya manusia harus memberikan fasilitas perusahaan kepada para karyawan sehingga karyawan tetap merasa nyaman dalam bekerja. Fasilitas tersebut antara lain seperti upah/gaji, perumahan, jaminan hari tua, lingkungan kerja yang nyaman, kesehatan dan keselamatan kerja.

Dari paparan di atas maka penulis tertarik untuk meneliti tentang "Pengaruh Manajemen Sumber Daya Manusia Terhadap Keselamatan Kerja Karyawan Paada Kantor PLN Dolopo Kab. Madiun“.

"Jaminan sosial tenaga kerja (Jamsostek) adalah suatu perlindungan bagi tenaga kerja dalam bentuk santunan berupa uang sebagai pengganti sebagian dari penghasilan yang hilang atau berkurang dan pelayanan sebagai akibat peristiwa atau keadaan yang dialami oleh tenaga kerja berupa kecelakaan kerja, sakit, hamil, bersalin, hari tua, dan meninggal dunia". (UURI Nomer 3 Tahun 1992, dalam Siswanto Sasrohadiwiryo, 2005: 114).

Siswanto Sastrohadiwiryo (2005: 114) menyatakan "kemanfaatan jaminan sosoail tenaga kerja pada hakikatnya bersifat dasar untuk menjaga harkat dan mertabat tenaga kerja. Dengan kemanfaatan tersebut pembiayaanya dapat ditekan seminimum mungkin sehingga dapat dijangkau oleh setiap pengusaha dan tenaga kerjanya".

Suyadi Prawirosentono (2012: 102), berpendapat bahwa "faktor yang mempengaruhi keselamatan kerja pada umumnya ada 3 hal utama yakni :

1) Keadaan pekerja sendiri (human factor/ human error)

Keadaan karyawan meliputi sikap, sifat dan tingkah laku karyawan dalam menghadapi pekerjaan ditempat kerjanya. Ada kalanya sifat, sikap, dan pendidikan mempengaruhi cara kerja seseorang.

2) Keadaan mesin dan alat-alat kerja (machine and tools condition)

Mesin dan peralatan produksi dapat meru- 
pakan sumber kecelakaan kerja. Bukan saja sifat dari mesin dan peralatan produksi itu sendiri, namun tata letaknya juga dapat mempengaruhi keselamatan kerja

3) Keadaan Lingkungan Kerja (work environment)

Lingkungan kerja sangat mempengaruhi morale (suasana kerja) para karyawan baik lingkungan kerja fisik maupun lingkungan yang bersfat rohani, dalam hal ini lingkungan kerja fisik yang baik akan mempertinggi produktifitas kerja. Disamping mengurangi kelelahan yang berarti dapat menaikan produksi.

Dari penjelasan diatas maka dapat ditarik kesimpulan bahwa peran manajemen sumber daya manusia sangat dibutuhkan untuk menjaga keselamatan kerja karyawan.

\section{Manajemen sumber daya manusia}

Manajemen adalah proses pendayagunaan bahan baku dan sumber daya manusia untuk mencapai tujuan-tujuan yang ditetapkan. Proses ini melibatkan organisasi, arahan, koordinasi dan evaluasi orangorang guna mencapai tujuan-tujuan tersebut. Esensi manajemen adalah aktivitas bekerja dengan orang lain agar mencapai berbagai hasil. Melalui manajemen dilakukan proses pengintegrasian berbagai sumber daya dan tugas untuk mencapai berbagai tujuan organisasi yang telah ditentukan.

MSDM adalah penerapan secara tepat dan efektif dalam proses akusis, pendayagunaan, pengemebangan dan pemeliharaan personil yang dimiliki sebuah organisasi secara efektif untuk mencapai tingkat pendayagunaan sumber daya manusia yang optimal oleh organisasi tersebut dalam mencapai tujuan-tujuannya.

Sedangkan menurut Dessler (dalam Edy Sutrisno, 2010: 5) "manajemen sumber daya manusia dapat didefinisikan sebagai suatu kebijakan dan praktik yang dibutuhkan seseorang yang menjalankan aspek "Orang" atau sumber daya manusia dari posisi seorang manajemen, meliputi perektutmen, penyaringan, pelatihan, pengimbalan dan penilaian".

MSDM adalah proses yang terdiri dari perencanaan, pengorganisasian, pimpinan dan pengendalian kegiatan-kegiatan yang berkaitan dengan analisis pekerjaan, evaluasi pekerjaan, pengadaan, pengembngan, kompensasi, promosi dan pemutusan hubungan kerja guna mencapai tujuan yang telah ditetapkan.

Agar tujuan dari sebuah manajemen sumber daya manusia dapat berjalan dengan lancar, perlu memanfaatkan fungsi-fungsi manajemen. Fungsi manajemen yang dimaksud menurut Edi Sutrisno (2010: 9) adalah (1) perencanaan, (2) pengorganisasian, (3) pengarahan dan pengadaan, (4) pengendalian, (5) pengembangan, (6) kompensasi, (7) pengintegrasian, (8) pemeliharaan, (9) kedisiplinan, (10) pemberhentian.

Vaithzal Rivai (2004: 6) menyatakan “Tanpa adanya unsur SDM dalam perusahaan, tidak mungkin perusahaan tersebut dapat bergerak dan berjalan menuju yang diinginkan, SDM adalah seseorang yang siap, mau dan mampu memberi sumbangan terhadap usaha pencapaian tujuan organisasi”. Dengan berpegang pada definisi tersebut, kita harus memahami bahwa sumber daya manusia dapat diartikan sebagai sumber dari kekuatan yang berasal dari manusiamanusia yang dapat didayagunakan oleh organisasi. Sehingga tidak dapat dipungkiri setiap perusahaan besar sangat mementingkan bahkan memanjakan karyawan dengan fasilitas yang mereka berikan, tentu saja berkaitan juga dengan prestasi kerja karyawan tersebut. Hai ini merupakan dasar bagi setiap aktifitas manajemen sumber daya manusia pada setiap bidang dalam organisasi.

Berdasarkan penjelasan diatas dapat disimpulkan bahwa untuk mengatasi suatu 
masalah seorang manajer dapat menerapkan metode mana yang paling efektif dan efisien untuk mengatasi masalah yang dihadapinya, tentu saja semua tergantung pada situasi dan kondisinya.

Kerangka berfikir adalah sebuah pemahaman yang melandasi pemahamanpemahaman yang lainnya. Untuk mendapat sebuah kerangka berfikir akan suatu hal bukan suatu yang mudah, diperlukan suatu pemikiran yang mendalam, tidak menyimpulkan hanya dari fakta, atau hanya dari sekedar informasi-informasi yang terpenggal. Kerangka berpikir berbeda dengan sekumpulan informasi atau hanya sekedar sebuah pemahaman.

Kerangka pemikiran disusun berdasarkan variable dalam penelitian yaitu manajemen sumber daya manusia dan keselamatan kerja karyawan. Pemimpin yang baik adalah pemimpin yang memperhatikan keselamatan kerja karyawan, pengelolaan menejemen sumber daya manusia yang baik nantinya akan memudahkan seorang karyawan dalam bekerja sehingga karyawan tersebut tetap fokus untuk melaksanakan tugasnya.

Sehingga Manajemen sumber daya manusia (variable X) sangat mempengaruhi keselamatan kerja karyawan ( Variabel Y).

\section{METODE PENELITIAN}

Tempat penelitian diadakan di Kantor PLN Kota Dolopo Kab. Madiun. Alasan pemilihan tempat penelitian adalah: (1) Belum ada penelitian serupa yang dilakukan di Kantor PLN Dolopo Kab. Madiun. (2) Agar dapat membantu jika ada peneliti lain yang ingin meneliti atau menyempurnakan penelitian tersebut. Jumlah karyawan pada Kantor PLN Dolopo Kab. Madiun sejumlah 40 orang, yaitu dengan pegawai tetap sebanyak 13 orang dan karyawan Outsourcing sebanyak 27 orang. Metode penelitian yang digunakan dalam penelitian ini adalah metode penelitian kuantitatif. Adapun rancangan penelitian yang digunakan dalam penelitian ini adalah rancangan penelitian deskriptif. Variabel independen atau variabel bebas dalam penelitian ini adalah manajemen sumber daya manusia, Variabel dependen atau variable terikat dalam penelitian ini adalah keselamatan kerja karyawan.

\section{Teknik pengumpulan data}

Metode observasi digunakan oleh peneliti untuk mengumpulkan data perusahaan yang menyangkut keselamatan kerja seperti usaha yang dilakukan oleh perusahaan untuk menjaga keselamatan karyawan dan alat-alat yag digunakan apakah sesuai dengan standar keselamata kerja karyawan. Metode kuesioner digunakan untuk meneliti tingkat keselamatan kerja yang dirasakan oleh karyawan dan kepuasan karyawan terhadap tingkat keselamatan kerja yang diberikan perusahaan. Metode wawancara digunakan untuk menggali informasi tentang manajemen sumber daya manusia dan keselamatan kerja karyawan.

\section{Instrument Penelitian}

Dalam penelitian ini, peneliti menggunakan instrumen penelitian berupa pedoman angket yang berisi pertanyaanpertanyaan yang akan ditanyakan pada narasumber yaitu manajer sumber daya manusia dan karyawan pada Kantor PLN Dolopo Kab. Madiun. Veithzal Rivai (2005: 14) mengatakan bahwa indikator manajemen sumber daya manusia meliputi fungsi-fungsi manajemen sumnber daya manusia dan pendekatan dalam manajemen sumber daya manusia. Sedangkan Siswanto Sasrohadiwiryo (2005: 47), mengatakan bahwa indikator dari keselamatan kerja karyawan meliputi undang-undang dan peraturan tentang keselamatan kerja kebijakan keselamatan kerja dan pemberian jaminan sosial tenaga kerja. 
Instrumen untuk penelitan ini menggunakan angket dengan Skala Likert. Skala Likert digunakan untuk mengukur sikap pendapat, persepsi seseorang atau sekelompok tentang kejadian atau gejala sosia. Dengan menggunakan skala likert maka variabel yang akan diukur dijabarkan menjadi dimensi dimensi dijabarkan menjadi sub variabel dijabarkan lagi menjadi indikator-indikator yang dapat diukur.

\section{HASIL PENELITIAN}

\section{Variabel Manajemen Sumber Daya Ma-} nusia dan Keselamatan Kerja Karyawan

Dideskripsikan dari variabel manajemen sumber daya manusia dengan jumlah data $(\mathrm{N})$ sebanyak 40 orang memiliki deskripsi data sebagai berikut: (a) Nilai ratarata hitung (mean) sebesar 40.20; (b) Median sebesar 40.00; (c) Modus sebesar 40.00; (d) Nilai Minimum sebesar 29.00; (e) Nilai Maximum sebesar 5.00.

Dideskripsikan dari variabel keselamatan kerja karyawan dengan jumlah data (N) sebanyak 40 orang memiliki deskripsi data sebagai berikut: (a) Nilai rata-rata hitung (mean) sebesar 40.13; (b) Median sebesar 40.00; (c) Modus sebesar 40.00; (d) Nilai minimum sebesar 20.00; (e) Nilia Maximum sebesar 50.00.

Uji reliabilitas terhadap angket menajemen sumber daya manusia diperoleh nilai Cronbach's Alpha masing-masing sebesar 0,873 dan 0,792. Karena nilai Cronbach's Alpha lebih dari 0,6 maka dapat dikatakan bahwa data yang telah dikumpulkan melalui angket manajemen sumber daya manusia dan keselamatan kerja karyawan reliable (dapat dipercaya).

\section{Hasil Uji Analisis Regresi Linier Sederhana}

Atas dasar perhitungan diatas dapat dibuat garis regresi sebagai berikut $\mathrm{Y}=17,091+0,573 \mathrm{X}$, artinya apabila mana jemen sumber daya manusia ditingkatkan satu kali akan terjadi kenaikan keselamatan kerja karyawan sebanyak $0,573 \%$ apabila faktor lainya tetap.

\section{Hasil Uji Korelasi}

Berdasarkan data diatas diketahui bahwa besarnya nilai $r_{\text {hitung }}$ adalah 0,659 dan $\mathrm{r}_{\text {tabel }} 0,312$ dilain pihak besarnya $\operatorname{Sig}_{\text {hitung }} 0,000$ dan $\operatorname{Sig}_{\text {pro }}$ 0,05. Hal ini berarti bahwa nilai $r_{\text {hitung }} \geq r_{\text {tabel }}(0,659 \geq 0,312)$ atau $\operatorname{Sig}_{\text {hit }} \leq \operatorname{Sig}_{\text {pro }}$ $(0,000 \leq 0,05)$. Atas dasar korelasi tersebut dapat disimpulhan Ho ditolak, artinya ada hubungan antara Manajemen Sumber Daya Manusia dan Keselamatan Kerja Karyawan pada Kantor PLN Dolopo Kab. Madiun.

\section{Hasil Uji t}

Berdasarkan data diatas diketahui bahwa besarnya nilai $r_{\text {hitung }}$ adalah 0,659 dan $\mathrm{r}_{\text {tabel }}$ 0,312 dilain pihak besarnya Sig $_{\text {hitung }}$ 0,000 dan $\mathrm{Sig}_{\text {pro }}$ 0,05. Hal ini berarti bahwa nilai $r_{\text {hitung }} \geq r_{\text {tabel }}(0,659 \geq 0,312)$ atau $\operatorname{Sig}_{\text {hit }} \leq$ $\operatorname{Sig}_{\text {pro }}(0,000 \leq 0,05)$. Atas dasar korelasi tersebut dapat disimpulhan Ho ditolak, artinya ada hubungan antara Manajemen Sumber Daya Manusia dan Keselamatan Kerja Karyawan pada Kantor PLN Dolopo Kab. Madiun.

\section{Simpulan Hasil Analisis}

Atas dasar hasil pengujian Hipotesis dapat diambil simpulan sebagai berikut

\section{Simpulan Uji Analisis Regresi Linier Sederhana}

Dapat dilihat hasil persamaan garis regresi $Y=17,091+0,573 X$, artinya apabila manajemen sumber daya manusia ditingkatkan satu kali akan terjadi kenaikan keselamatan kerja karyawan sebanyak $0,573 \%$, apabila faktor yang lainya tetap. Atas dasar korelasi tersebut dapat disimpulkan Ho ditolak,artinya ada hubungan antara 
Manajemen Sumber Daya Manusia Terhadap Keselamatan Kerja Karyawan pada Kantor PLN Dolopo, Kab Madiun. Ho ditolak.

\section{Simpulan Uji Regresi}

Berdasarkan data yang telah dihitung, diketahui bahwa besarnya nilai $r_{\text {hitung }}$ adalah 0,659 dan $r_{\text {tabel }} 0,312$ dilain pihak besarnya Sig $_{\text {hitung }}$ 0,000 dan $\operatorname{Sig}_{\text {pro }}$ 0,05. Hal ini berarti bahwa nilai $r_{\text {hitung }} \geq r_{\text {tabel }}(0,659 \geq 0,312)$ atau $\operatorname{Sig}_{\text {hit }} \leq \operatorname{Sig}_{\text {pro }}(0,000 \leq 0,05)$. Atas dasar korelasi tersebut dapat disimpulhan Ho ditolak, artinya ada hubungan antara Manajemen Sumber Daya Manusia dan Keselamatan Kerja Karyawan pada Kantor PLN Dolopo Kab. Madiun.

\section{Simpulan Uji t}

Berdasarkan Uji t nilai $\mathrm{t}_{\text {hitung }}$ adalah 7,189 dan $t_{\text {tabel }} 1,685$, dilain pihak besarnya $\operatorname{sig}_{\text {hitung }}$ 0,000 dan $\operatorname{Sig}_{\text {pro }}$ 0,05, hal ini berarti bahwa nilai $\mathrm{t}_{\text {hitung }}>\mathrm{t}_{\text {tabel }}(7,189>1,685)$ atau $\operatorname{Sig}_{\text {hitung }}<$ $\operatorname{Sig}_{\text {pro }}(0,000<0,05)$. Atas dasar korelasi tersebut dapat disimpulkan Ho ditolak, artinya ada beda pengaruh antara Manajemen Sumber Daya Manusia Terhadap Keselamatan Kerja Karyawan pada Kantor PLN Dolopo, Kab Madiun.

\section{Pembahasan uji korelasi}

Untuk uji korelasi diperoleh besarnya $\mathrm{r}_{\text {hitung }}$ adalah 0,659 dan $\mathrm{r}_{\text {tabel }} 0,312$ dilain pihak besarnya $\operatorname{Sig}_{\text {hitung }} 0,000$ dan $\operatorname{Sig}_{\text {pro }}$ 0,05. Hal ini berarti bahwa nilai $r_{\text {hitung }} \geq r_{\text {tabel }}(0,659 \geq 0,312)$ atau $\operatorname{Sig}_{\text {hit }} \leq \operatorname{Sig}_{\text {pro }}(0,000 \leq 0,05)$. Atas dasar korelasi tersebut dapat disimpulhan $\mathrm{Ho}$ ditolak, artinya ada hubungan antara Manajemen Sumber Daya Manusia dan Keselamatan Kerja Karyawan pada Kantor PLN Dolopo Kab. Madiun.

\section{Pembahasan ujit}

Berdasarkan Uji t nilai $t_{\text {hitung }}$ adalah 7,189 dan $\mathrm{t}_{\text {tabel }} 1,685$ dilain pihak besarnya Sig $_{\text {hitung }}$
0,000 dan $\operatorname{Sig}_{\text {pro }}$ 0,05, hal ini berarti bahwa nilai $\mathrm{t}_{\text {hitung }} \geq \mathrm{t}_{\text {tabel }}(7,189 \geq 1,685)$ atau $\operatorname{Sig}_{\text {hitung }}$ $\leq \operatorname{Sig}_{\text {pro }}(0,000 \leq 0,05)$. Atas dasar uji beda pengaruh tersebut dapat disimpulkan Ho ditolak, artinya ada beda pengaruh antara Manajemen Sumber Daya Manusia terhadap Keselamatan Kerja Karyawan pada Kantor PLN Dolopo Kab. Madiun.

Dari hasil penelitian menunjukan bahwa manajemen sumber daya manusia mempunyai hubungan sekaligus pengaruh terhadap keselamatan kerja. Artinya apabila diterapkan manajemen sumber daya manusia yang baik maka akan tercipta keselamatan kerja yang dibutuhkan karyawan sehingga dapat bekerja dengan tenang, efektif dan efisien.

Manajemen sumber daya manusia dalam menjalankan fungsinya akan mendistribusikan pekerja keberbagai bidang organisasi sesuai kebutuhannya. Ini menunjukan bahwa manajemen sumber daya manusia mempunyai keterkaitan dengan manajemen lain termasuk bidang keselamatan kerja karyawan.

"Sama seperti sistem manajemen lain, sistem manajemen keselamatan kerja adalah pengoperasian fungi-fungsi manajemen kedalam kedalam kegiatan-kegiatan organiasi yang barkaitan dengan keselamatan kerja karyawan sesuai tujuan utama dari sistem manajemen keselaatan kerja", (Wilson Bangun, 2012: 387).

\section{PENUTUP}

\section{Kesimpulan}

Manajemen sumber daya manusia di Kantor PLN Dolopo Kab. Madiun cukup efektif dan efisien. Hal ini dilihat dari tingkat keselamatan kerja yang cukup tinggi. Berdasarkan data yang telah diteliti diketahui bahwa besarnya nilai $r_{\text {hitung }}$ adalah 0,659 dan $\mathrm{r}_{\text {tabel }} 0,312$ dilain pihak besarnya $\operatorname{Sig}_{\text {hitung }} 0,000$ dan $\operatorname{Sig}_{\text {pro }}$ 0,05. Hal ini berarti bahwa nilai $r_{\text {hitung }} \geq r_{\text {tabel }}(0,659 \geq 0,312)$ atau $\operatorname{Sig}_{\text {hit }} \leq \operatorname{Sig}_{\text {pro }}$ $(0,000 \leq 0,05)$. Atas dasar korelasi tersebut 
dapat disimpulhan Ho ditolak, artinya ada hubungan antara Manajemen Sumber Daya Manusia dan Keselamatan Kerja Karyawan pada Kantor PLN Dolopo Kab. Madiun.

Manajemen sumber daya manusia mempunyai pengaruh terhadap keselamatan kerja karyawan pada Kantor PLN Dolopo Kab. Madiun. Terbukti dari hasil analisis regresi yang memuat hasil korelasi, uji t. Dari hasil korelasi uji t diperoleh garis regresi yaitu $\mathrm{Y}=17,091+0,573 \mathrm{X}$, artinya apabila manajemen sumber daya manusia ditingkatkan satu kali akan terjadi kenaikan keselamatan kerja karyawan sebanyak $0,573 \%$ apabila faktor lainya tetap. Sedangkan, $\mathrm{t}_{\text {hitung }} \geq \mathrm{t}_{\text {tabel }}$ $(5,408 \geq 1,685)$ atau $\operatorname{Sig}_{\text {hitung }} \leq \operatorname{Sig}_{\text {pro }}(0,000 \leq$ $0,05)$. Jadi berdasarkan uji korelasi uji t, dapat disimpulkan ada pengaruh Manajemen Sumber Daya Manusia terhadap Keselamatan Kerja Karyawan pada Kantor PLN Dolopo Kab. Madiun.

Banyak yang dilakukan oleh manajer untuk meningkatkan keselamatan kerja karyawan, langkah-langkahnya antara lain seperti yang dikemukakan oleh Suyadi Prawirosentono (2002: 103) adalah sebagai berikut:

a. Menciptakan kondisi kerja karyawan yang baik.

Hal yang perlu diperhatikan adalah merencanakan dan menciptakan kondisi psikologis dan fisik para karyawan agar dapat bekerja secara aman dan tentram. Hal ini hanya dapat dicapai antara lain dengan mengadakan pelatihan (job training) sebelum karyawan bekerja.

b. Menciptakan kondisi mesin dan peralatan yang baik.

Tata letak (layout) mesin dan berbagai peralatan produksi harus diatur dengan baik agar menunjang kelancaran proses produksi, dan menunjang keselamatan dan kesehatan kerja. Selain itu seluruh mesin dan peralatan harus didukung dengan alat kontrol yang berfungsi baik.

\section{Saran}

1. Bagi Manajer Sumber Daya Manusia di Kantor PLN Dolopo Kab. Madiun.

Peningkatan keselamatan kerja bisa melalui sistem manajemen sumber daya manusia yang baik seperti pemberian pelatihan kepada karyawan dan penambahan alat-alat kerja yang menunjang keselamatan kerja. Dengan demikian diharapkan tercipta kerjasama dan tercapai tujuan perusahaan dan karyawan.

2. Bagi Karyawan Kantor PLN Dolopo Kab. Madiun.

Karyawan diharapkan mampu meningkatkan keselamatan kerja dalam melaksanakan segala aktifitas. Sehingga dapat tercapai tujuan perusahaan serta dapat bertanggung jawab terhadap tugas yang telah diberikan.

3. Bagi Peneliti Lain

Peneliti diharapkan mampu mengembangkan penelitian yang pernah ada, serta mencari faktor-faktor lain yang mempunyai pengaruh bagi keselamatan kerja karyawan. Sehingga dengan adanya pengembangan penelitian dapat mengetahui cara meningkatkan keselamatan kerja karyawan dalam perusahaan maupun organisasi.

\section{DAFTAR PUSTAKA}

Cholid Narbuko, Abu Ahmad. Metodologi Penelitian. Jakarta: PT. Bumi Aksara.

Edi Sutrisno. 2010. Manajemen Sumber Daya Manusia. Jakarta: Pranada Media Group

Gabriel Amin Silalahi. 2003. Metodologi Penelitian Dan Studi Kasus. Sidoarjo: Citra Media.

(http://andyseptianwibisono.wordpress.com/ 2013/01/18/artikel-manajemensumber-daya-manusia/). 
(http://id.wikipedia.org/wiki/Perusahaan_Lis trik Negara).

Husain Umar. 2011. Metodologi Penelitian Untuk Skripsi Dan Tesis Bisnis. Jakarta: PT. RajaGrafindo Persada.

IKIP PGRI MADIUN. 2013. Pedoman Penulisan Skripsi. Madiun: Pusat Penerbitan Kampus.

Iqbal Hasan. 2004. Analisis Data Penelitian Dengan Statistik. Jakarta: PT. Bumi Aksara.

Malayu S.P Hasibuan. 2002. Manajemen Sumber Daya Manusia. Jakarta: PT. Bumi Aksara.

Mathis Jakson. 2009. Human Resource Manajemen. Jakarta: Salemba Empat.

Siswanto Sastrohadiwiryo. 2005. Manajemen Tenaga Kerja Indonesia. Jakarta: PT. Bumi Aksara
Sondang P. Siagian. 2003. Manajemen Sumber Daya Manusia. Jakarta: PT. Bumi Aksara

Sugiono. 2007. Metode Penelitian Kuantitatif, kualitatif Dan $R \& D$. Bandung: Alfabeta.

Suharsimi Arikunto. 2009. Manajemen Penelitian. Jakarta: PT. Rineka Cipta.

Suyadi Prawirisentono. 2002. Pengantar Bisnis Moderen. Jakarta: PT. Bumi Aksara.

Wilson Bangun. 2012. Manajemen Sumber Daya Manusia: Erlangga

Vaithzal Rivai. 2004. Manajemen Sumber Daya Manusia Untuk Perusahaan. Jakarta: PT. RajaGrafindo Persada 